\title{
Erratum to: Theobroma cacao L. pathogenesis-related gene tandem array members show diverse expression dynamics in response to pathogen colonization
}

\author{
Andrew S. Fister ${ }^{1}$, Luis C. Mejia ${ }^{2,3}$, Yufan Zhang ${ }^{4}$, Edward Allen Herre ${ }^{3}$, Siela N. Maximova ${ }^{1,5}$ \\ and Mark J. Guiltinan ${ }^{1,5^{*}}$
}

\section{Erratum}

The original version of the manuscript [1] contained an incorrectly named Criollo gene ID on chromosome 1 in the first sentence, under the subheading "Organization of PR gene families into tandem arrays". The second gene on chromosome 1, Tc\#\#_g\#\#\#\#\#, should therefore be Tc01_g000020.

\section{Author details \\ 'The Huck Institutes of the Life Sciences, The Pennsylvania State University, 422 Life Sciences Building, University Park 16802, PA, USA. ${ }^{2}$ Institute for Scientific Research and High Technology Services (INDICASAT-AIP), Panama City, Panama. ${ }^{3}$ Smithsonian Tropical Research Institute (STRI), Unit 9100, Box 0948, Balboa, Ancon DPO AA 34002-9998, Panama. ${ }^{4}$ Department of Electrical Engineering, Princeton University, Princeton, NJ 08544, USA. ${ }^{5}$ The \\ Department of Plant Science, The Pennsylvania State University, 422 Life Sciences Building, University Park 16802, PA, USA.}

Received: 23 June 2016 Accepted: 2 September 2016

Published online: 07 September 2016

\section{References}

1. Fister AS, et al. Theobroma cacao L. pathogenesis-related gene tandem array members show diverse expression dynamics in response to pathogen colonization. BMC Genomics. 2016;17:363. doi:10.1186/s12864-016-2693-3.

\footnotetext{
*Correspondence: mjg9@psu.edu

${ }^{1}$ The Huck Institutes of the Life Sciences, The Pennsylvania State University, 422 Life Sciences Building, University Park 16802, PA, USA

${ }^{5}$ The Department of Plant Science, The Pennsylvania State University, 422 Life Sciences Building, University Park 16802, PA, USA

Full list of author information is available at the end of the article
}

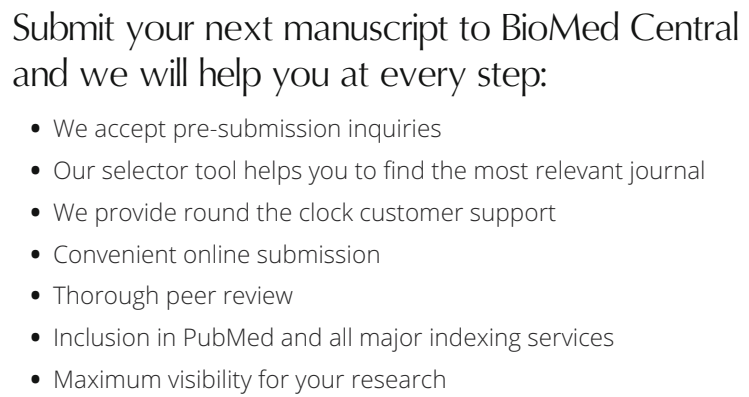
and we will help you at every step:

- We accept pre-submission inquiries

- Our selector tool helps you to find the most relevant journal

- We provide round the clock customer support

- Convenient online submission

- Thorough peer review

- Inclusion in PubMed and all major indexing services

- Maximum visibility for your research

Submit your manuscript at www.biomedcentral.com/submit 